\title{
Muhammad Asad's the Message of the Qur'an
}

\author{
Nadzrah Ahmad ${ }^{1, *}$, Ahmad Nabil B. Amir ${ }^{2}$ \\ ${ }^{1}$ Department of Qur'an and Sunnah, Kulliyyah of Islamic Revealed Knowledge and Human Sciences, \\ International Islamic University, Malaysia \\ ${ }^{2}$ Islamic Renaissance Front, Level 8, Pavilion KL, 168 Jalan Bukit Bintang, 55100 Kuala Lumpur, Wilayah Persekutuan, Malaysia
}

Copyright $\bigcirc 2016$ by authors, all rights reserved. Authors agree that this article remains permanently open access under the terms of the Creative Commons Attribution License 4.0 International License

\begin{abstract}
This paper aims to analyze the method of Qur'anic hermeneutic (al-ta'wil) as set forth by Muhammad Asad in his magnum opus, The Message of the Qur'an. Its objective is to study the underlying method he crafted in the commentary and the influence it projected in the Muslim world. The study of Muhammad Asad's method is crucial to gain an understanding of his modern worldviews, and the underlying pattern of scientific and rational thought grounded in his work, which reflected the renewal project of Islam advocated by Shaykh Muhammad Abduh and Sayid Muhammad Rashid Rida in Tafsir al-Manar.
\end{abstract}

Keywords Muhammad Asad, The Message of the Qur'an, Methodology, Hermeneutic, Tafsir

\section{Introduction}

This paper presents the principal framework of tafsir as outlined by Muhammad Asad in his unmatched translation and commentary of the Qur'an, The Message of the Qur'an. It strives to analyze its underlying method and principle and the idealism and views that impacted his work. The Message advocated rational principle (al-ra' $y$ ) based on the teaching of Shaykh Muhammad 'Abduh and Sayid Muhammad Rashid Rida in Tafsir al-Manar, that brought out dynamism and scientific exposition of the ayah as profoundly developed by Asad [1] in his tafsir:

"The reader will find in my explanatory notes frequent references to views held by Muhammad 'Abduh (1849-1905). His importance in the context of the modern world of Islam - can never be sufficiently stressed. It may be stated without exaggeration that every single trend in contemporary Islamic thought can be traced back to the influence, direct or indirect, of this most outstanding of all modern Islamic thinkers. The Qur'an-commentary planned and begun by him was interrupted by his death in 1905; it was continued (but unfortunately also left incomplete) by his pupil Rashid
Rida under the title Tafsir al-Manar, and has been extensively used by me."

\section{Methodology}

This study is based on evaluative research in the library and a fieldwork. It investigates Muhammad Asad"s monumental work, The Message of the Qur'an and other important works of him that informed his progressive ideas and dynamic approach to the Qur'an. It will also look into previous works that illustrated his hermeneutical philosophy, and critical and rational outlook and explicit project of reform in his commentary. The study also survey the background that provided the setting for this work, i.e., in Switzerland, Morocco and Spain, in his sojourn for 17 years to accomplish The Message. This constitutes significant material and source in preparing our qualitative and quantitative analysis of his method and on the historical setting and background of the work.

\section{The Message of the Qur'an}

The first part of this work, comprising the translation and commentary of the first ten surah of the Qur'an (al-Baqarah - The Heifer to al-Tawbah - The Repentance) was published in 1964. It took him almost 17 years to accomplish the entire work of tafsir that constitute about 1000 pages, published by Dar al-Andalus, Gibraltar in 1980. The publication marked the momentous occasion of the celebration of the new Islamic millennium, that it was "published by the Graced of God at the beginning of the fifteenth century of the Hijrah" [2].

The work portrayed profound views and influential ideal of the mufassir in understanding the essence and spirit of Divine writ. It projects significant reform and unprecedented method in approaching the text. Asad's commentary presents dynamic understanding of the Qur'an based on rational and scientific analysis that defined its underlying method and framework. In his Prologue to the new edition of the book, Gai Eaton [3], a prominent British Muslim hailed him as the 
leading exponent of rational Islam and acclaimed the profound important of his work:

\section{"There exists no more useful guide to the Qur'an in the English language than Muhammad Asad's translation and commentary, and no other translator has come so close to conveying the meaning of the Qur'an to those who may not be able to read the Arabic text or the classical commentaries."}

This outstanding work was hailed as a powerful and influential work of commentary, as depicted by The Independent [4] in its obituary to Asad of his important masterpiece:

"In its intellectual engagement with the text and in the intimate, subtle and profound understanding of the pure classical Arabic of the Koran, Asad"s interpretation is of a power and intelligence without rival in English."

This monumental work was dedicated "To People Who Think", echoing the dynamic principle of ijtihad (independent reasoning) and rational interpretation of the Qur'an as represented in the text. In his foreword to the work Asad [5] emphasized the significant important of reason in understanding the text and the need to produce a modern and scientific interpretation, giving rational explanation to the inexhaustible and deep-layer meaning of the text:

"although it is impossible to "reproduce" the Quran as such in any other language, it is none the less possible to render its message comprehensible to people who, like most Westerners, do not know Arabic...well enough to find their way through it unaided."

This work was alluded to in his book, This Law of Ours and Other Essays - compiled by Pola Hamida Asad - in which he set forth a chapter entitled "The Message of the Qur'an" that provides a brief exposition of the spiritual and moral significance of the Qur'an in the modern age. It represents his thoughts of some aspects of "this eternal, inexhaustible" depth of the Holy Book - the subject of his talk delivered at a Conference of the Islamic Council, in London, April 1980:

"I must confess that at first I was somewhat taken aback by this request - for the simple reason that "The Message of the Qur'an" is the title of my translation of and commentary on the Holy Qur'an which has just been published after more than seventeen years of labour. Since this work consists of about 1000 printed pages, it seemed to me that I could not profitably add anything to it within the limited compass of a talk such as the present one...And so, despite my just having published 1000 pages on "The Message of the Qur'an", I now stand before you ready to offer a few more thoughts on one or two particular aspects of this eternal, inexhaustible subject." [6]

\section{Asad's Commentary (Tafsir)}

The method of tafsir developed by Asad, was profoundly inspired by rational argument brought out in classical works of tafsir such as of Abu Muslim al-Isfahani, al-Tabari, Fakhr al-Din al-Razi, and al-Zamakhshari. The monumental work of Muhammad Abduh and Rashid Rida, Tafsir al-Manar has also exercise great influence in his approach. It was the principal and key reference that has significant impact in the rational method constructed by Asad, as evidently reflected in his argumentative commentary, that carries extensive reference to al-Manar, which promotes progressive ideas and dynamic spirit of Islam and the primacy of 'aql, as emphasized by Asad [7] in many occasions:

“every Qur'anic verse or statement is directed to reason and therefore must be comprehensible...the spirit of the Qur'an could not be correctly understood if we read it merely in the light of later ideological developments, losing sight of its original purport and meaning. In actual fact we are bent to become intellectual prisoners of others who were themselves prisoners of the past and had little to contribute to the resurgence of Islam in the modern world:"

The methodological framework, systematically formulated by Asad in his erudite translation and commentary of the Qur'an, can be succinctly summarized here:

1. To interpret the Qur'an with the Qur'an and rigorously authenticated hadith of the Prophet (saw).

2. To identify the main ideas and principle theme in each surah. For example his striving to brought out the major theme of "God's unfathomable direction of men's affair" as illustrated in his introduction to Surah Yusuf (as):

"The whole of this surah might be described as a series of variations on the theme "judgment [as to what is to happen] rests with none but God", explicitly enunciated only in verse 67 , but running like an unspoken leitmotif throughout the story of Joseph." [8]

3. To investigate the epistemological, historical origin of the designation of each surah, as marked in his argument of the name of surah al-Ma 'un (Assistance):

"The name of this surah, which was revealed in the early years of the Prophet's (saw) mission (probably after surah 102) is derived from the word al-ma'un occurring in the last verse." [9]

4. To set forth rational exposition and commentary based on 'aql (reason) and ijtihad (independent reasoning), that carries differing views and thought of leading fuqaha (jurist consult) with high level of ijtihad. This was outstandingly portrayed in his analysis of surah 5:96: "Lawful to you is all water-game, and what the sea brings forth, as a provision for you [who are settled] as well as for travellers, although you are forbidden to hunt on land while you are in the state of pilgrimage." 
Asad [10] marked:

Lit., "the game of the sea and its food". Since the term bahr denotes any large accumulation of water, the classical commentators and jurists agree that the above ordinance comprises all water-game, whether derived from seas, rivers, lakes or ponds (Tabari). The pronoun in ta 'amuhu (lit., "its food") relates to the word bahr, and thus indicates the fish and other marine animals which may have been cast forth by the waves onto the shore (Tabari, Razi). Zamakhshari, however, regards the pronoun as relating to the object of the game (sayd) as such, and, consequently, understands the phrase as meaning "the eating thereof". Either of these two readings is agreeable with the text inasmuch as the above verse lays down that all kinds of water-game are lawful to a believer - even if he is in the state of pilgrimage - whereas hunting on land (sayd al-barr) is forbidden to the pilgrim."

5. To critically investigates the Jewish and Christians source extensively brought out in classical works of tafsir, by establishing its authenticity and coherency with the Qur'an, as accounted in his explanatory note to verse 2 of surah Maryam: "An account of the grace which thy Sustainer bestowed upon His servant Zachariah" (19:2). Asad [11] notes:

"According to the account in the Gospels, not contradicted by the Qur'an, Zachariah's wife Elisabeth was a cousin of Mary, the mother of Jesus (Cf. Luke i, 36)."

6. To identify the Makkiyah and Madaniyah surah, or period of revelation, by looking into its circumstantial evidence, and authentic tradition (athar) narrating its condition and circumstances, as marked in his heading introducing surah Al-Kawthar (Good in Abundance):

"Whereas most of the authorities assign this surah to the early part of the Mecca period, Ibn Kathir considers it most probable that it was revealed at Medina. The reason for this assumption (shared by many other scholars) is to be found in an authentic hadith on the authority of Anas ibn Malik, who narrates - with a good deal of circumstantial detail - how the surah was revealed "while the Apostle of God was among us in the mosque" (Muslim, Ibn Hanbal, Abu Dawud, Nasa i). The "mosque" referred to by Anas can only have been the mosque of Medina: for, on the one hand, Anas - a native of that town - had never met the Prophet (saw) before the latter's exodus to Medina (at which time Anas was barely ten years old); and, on the other hand, there had been no mosque - i.e., a public place of congregational worship - available to the Muslims at Mecca before their conquest of that city in 8 H.”[12]

7. To expound the allegorical and figurative meaning instead of literal interpretation of the ayah, that set forth dynamic interpretation of its metaphoric connotation, as depicted in his commentary of surah 5:90: "O you who have attained to faith! Intoxicants, and game of chance, and idolatrous practices, and the divining of the future are but a loathsome evil of Satan's doing." Asad's [13] comments:

"As regards the expression "idolatrous practices" ansab, lit., "idolatrous altars"), see note 8 of this surah. This term has, I believe, been used here metaphorically, and is meant to circumscribe all practices of an idolatrous nature - like saint-worship, the attribution of "magic" properties to certain inanimate objects, the observance of all manner of superstitious taboos, and so forth."

8. To realized the essence and spirit of shariah, and its higher objective (maqasid) as to safeguard the maslahah (public interest) and uphold the rights and liabilities in implementing the law, as reflected in the holistic and comprehensive view of the Qur'an. This was argued in his commentary of surah 5:38: "Now as for the man who steals and the woman who steals, cut off the hand of either of them in requital for what they have wrought, as a deterrent ordained by God." Asad [14] notes:

"In a community or state which neglects or is unable to provide complete social security for all its members, the temptation to enrich oneself by illegal means becomes irresistible - and, consequently, theft cannot and should not be punished as severely as it should be punished in a state in which social security is a reality in the full sense of the word. If the society is unable to fulfil its duties with regard to every one of its members, it has no right to invoke the full sanction of criminal law (hadd) against the individual transgressor, but must confine itself to milder forms of administrative punishment. (It was in correct appreciation of this principle that the great Caliph 'Umar waived the hadd of hand-cutting)."

\section{Conclusions and Future Recommendation}

This paper has tried to expound fundamental principle of Qur'anic exegesis as constructed by Muhammad Asad in his magnum opus, The Message of the Qur'an. The underlying method of his work was grounded on rational philosophy and outlook that profoundly based on classical and modern works of tafsir, such as al-Razi (Tafsir al-Kabir), al-Zamakhshari (Tafsir al-Kashshaf), Ibn Kathir (Tafsir al-Qur'an al-Azim), Muhammad 'Abduh and Rashid Rida (Tafsir al-Manar). It strived to uphold the primacy of 'aql (reason), through its rational exposition and scientific interpretation of the ayah. This profound method of rational argument (al-ra'y) and explicit use of ijtihad implies his substantial effort to revealed intrinsic meaning, and deep-seated spirit of the Qur'an. Asad's hermeneutical 
approach carries significant contribution to reflect the underlying message and the allegorical and metaphorical implication of the ayat and the underlying idea and transcendental message of the Qur'an.

\section{The Importance of Study}

This study has great significance in advocating the modern ideal of Islam projected by Muhammad Asad in his tafsir that set forth rational interpretation and understanding of the Qur'an. This is important in bringing forth a coherence and consistent ideal of Islam and in realizing its aspiration for reform and reconstruction of thought and ijtihad. Analysing his modernist approach and reformist project in interpreting and explaining the meaning and contextualizing the text, Abdin Chande [15] said: "Despite its modernist agenda, it is a coherent translation which brings into sharp focus a particular modernist discourse on the Qur'an. The outcome of this approach is precisely in its style of picking and choosing meanings and interpretations which best suit the modernist project."

The tafsir's profound scope and analysis of spiritual, moral and physical aspect of Islam as illustrated in its erudite footnote, and its extensive references to modern and classical works of tafsir and constructive critics of the Old and New Testament has provide significant and dynamic argument projecting a balance and comprehensive understanding of the Qur'an in the modern context. This has profound meaning and implication for Muslim community in establishing meaningful dialogue and interaction with the West and in bridging the gap of ideas and civilization.

\section{REFERENCES}

[1] Asad, M. The Message of The Qur'ān, Dar al-Andalus: Gibraltar, 1980. p.14.

[2] Asad, M. This Law of Ours and Other Essays, Islamic Book Trust: Kuala Lumpur, 1987.

[3] Eaton, G. Prologue. In: Asad, M. The Message of The Qur'ān, The Book Foundation: London, 2008.

[4] Parker, M. The Independent. Monday 23 March 1992.

[5] Asad, M. The Message of The Qur'ān, Dar al-Andalus: Gibraltar, 1980.

[6] Asad, M. This Law of Ours and Other Essays, Islamic Book Trust: Kuala Lumpur, 1987. p.187

[7] Asad, M. The Message of The Qur'ān, Dar al-Andalus: Gibraltar, 1980.

[8] Asad, M. The Message of The Qur'ān, Dar al-Andalus: Gibraltar, 1980. p.499.

[9] Asad, M. The Message of The Qur'ān, Dar al-Andalus: Gibraltar, 1980. p.1297.

[10] Asad, M. The Message of The Qur'ān, Dar al-Andalus: Gibraltar, 1980. p.1314.

[11] Asad, M. The Message of The Qur'ān, Dar al-Andalus: Gibraltar, 1980. p.650.

[12] Asad, M. The Message of The Qur'ān, Dar al-Andalus: Gibraltar, 1980. p.1297.

[13] Asad, M. The Message of The Qur'ān, Dar al-Andalus: Gibraltar, 1980. p. 243.

[14] Asad, M. The Message of The Qur'ān, Dar al-Andalus: Gibraltar, 1980. p.213.

[15] Chande. A. Symbolism and Allegory in the Qur'ān. Muhammad Asad's Modernist Translation. Islam and Christian-Muslim Relations, Vol.15, No.1, January 2004, 79-89. 